\title{
KLF4 wt Allele
}

National Cancer Institute

\section{Source}

National Cancer Institute. KLF4 wt Allele. NCI Thesaurus. Code C73450.

Human KLF4 wild-type allele is located in the vicinity of $9 q 31$ and is approximately $5 \mathrm{~kb}$ in length. This allele, which encodes Krueppel-like factor 4 protein, is involved in the modulation of transcription. 